\title{
HUBUNGAN FLUKS METANA DAN DINITROGEN OKSIDA DENGAN KARAKTERISTIK TANAH SAWAH TADAH HUJAN DI JAWA TENGAH
}

\author{
A. Wihardjaka ${ }^{*}$, S. D. Tandjung ${ }^{2}$, B. H. Sunarminto ${ }^{3}$, E. Sugiharto ${ }^{4}$
}

(Diterima tanggal 15-11-2011; Disetujui tanggal 14-03-2012)

\begin{abstract}
ABSTRAK
Kondisi basah - kering tanah sawah tadah hujan yang silih berganti mempengaruhi dinamika gas rumah kaca metana dan dinitrogen oksida dalam tanah. Besarnya produksi $\mathrm{CH}_{4}$ dan $\mathrm{N}_{2} \mathrm{O}$ terkait dengan sifat fisik, kimia, dan biologi tanah sawah tadah hujan. Penelitian dilaksanakan di laboratorium untuk mengetahui hubungan antara fluk metana dan dinitrogen oksida dan karakteristik tanah sawah tadah hujan Inceptisol. Contoh tanah diinkubasi selama satu bulan dan dianalisis produksi $\mathrm{CH}_{4} \mathrm{dan}$ $\mathrm{N}_{2} \mathrm{O}$, dan karakteristik fisik, kimia, dan biologi tanah. Laju produksi metana dari tanah sawah tadah hujan Inceptisol berkorelasi positif secara nyata dengan kandungan $\mathrm{C}$ organik dan berkorelasi negatif dengan ketersediaan sulfat dan mangan dalam tanah. Produksi dinitrogen oksida dari tanah sawah tadah hujan Inceptisol berkorelasi positif secara nyata dengan kandungan nitrat dan berkorelasi negatif dengan ketersediaan mangan (Mn) dalam tanah dan kandungan lempung.
\end{abstract}

Kata kunci: metana, dinitrogen oksida, tanah sawah Inceptisol, tadah hujan

\begin{abstract}
In rainfed lowland ecosystem, the soil is not submerged continuously but is subjected to wetting and drying cycles. Alternating periods of soil oxidation and reduction resulting from the changing hydrological conditions lead to affect greenhouse gases dynamics of methane and nitrous oxide. The magnitude of $\mathrm{CH}_{4}$ and $\mathrm{N}_{2} \mathrm{O}$ productions relates to physical, chemical, biological properties of rainfed rice soils. The laboratory experiment was carried out to determine relationship between fluxes of $\mathrm{CH}_{4}$ and $\mathrm{N}_{2} \mathrm{O}$ and soil characteristicts of Inceptisols. Soil samples were incubated during a month and analyzed $\mathrm{CH}_{4}$ and $\mathrm{N}_{2} \mathrm{O}$ production and soil properties. The methane production rate correlated positively and significantly with organic $C$ content, however, it correlated negatively with sulphate and manganese availability in rainfed rice soils of Inceptisols. The nitrous oxide production correlated positively and significantly with soil nitrate, however, it correlated negatively with manganese (Mn) availability and clay content in soil under rainfed rice ecosystems.
\end{abstract}

Key words: methane, nitrous oxide, Inceptisols, rainfed rice field

\section{PENDAHULUAN}

Hingga kini beras masih merupakan salah satu komoditas utama dan strategis di Indonesia dalam memenuhi kecukupan pangan nasional. Beras juga merupakan sumber ekonomi bagi lebih dari 30 juta petani. Peningkatan produksi beras nasional dituntut sebesar $0,8-1 \%$ setiap tahun sebagai antisipasi dalam mengimbangi laju pertambahan jumlah penduduk 1,5\% setiap tahun. Pemenuhan kebutuhan beras nasional masih ditopang sawah beririgasi yang luasnya setiap tahun mengalami penciutan akibat alih

\footnotetext{
1) Balai Penelitian Lingkungan Pertanian, Jakenan, Pati Jawa Tengah

2) Fakultas Biologi Universitas Gadjah Mada, Yogyakarta

3) Fakultas Pertanian Universitas Gadjah Mada, Yogyakarta

4) Fakultas Matematika dan Ilmu Pengetahuan Alam Universitas Gadjah Mada, Yogyakarta
}

fungsi lahan. Optimalisasi pemanfaatan sawah tadah hujan memiliki prospek dan potensi besar sebagai areal produksi padi dalam menunjang ketahanan pangan.

Tanah sawah adalah produser nyata gas metana $\left(\mathrm{CH}_{4}\right)$ dan dinitrogen oksida $\left(\mathrm{N}_{2} \mathrm{O}\right)$. Potensi efek rumah kaca dari $\mathrm{CH}_{4}$ dan $\mathrm{N}_{2} \mathrm{O}$ masing-masing sebesar 27\% dan 16\% (Ko \& Kang, 2000; Johnson et al., 2007). Gas $\mathrm{CH}_{4}$ dihasilkan dari proses dekomposisi bahan organik secara anaerobik dengan melibatkan 
bakteri metanogen, sedangkan gas $\mathrm{N}_{2} \mathrm{O}$ adalah hasil proses nitrifikasi dan denitrifikasi dalam tanah sawah (Jain et al., 2000). Produksi $\mathrm{CH}_{4}$ dan $\mathrm{N}_{2} \mathrm{O}$ dalam tanah sawah dipengaruhi oleh tipe tanah, penggunaan lahan, kondisi ketersediaan air tanah, praktek budidaya tanaman pertanian (Wassmann \& Dobermann, 2006; Johnson et al., 2007).

Kondisi basah - kering silih berganti tanah sawah tadah hujan akibat curah hujan tidak menentu berpengaruh terhadap karakteristik tanah dan dinamika gas rumah kaca terutama metana dan dinitrogen oksida. Dinamika $\mathrm{CH}_{4}$ dan $\mathrm{N}_{2} \mathrm{O}$ dalam tanah sawah tadah hujan tergantung pada sifat fisik, kimia, biologi tanah, dan ketersediaan air tanah (Johnson et al., 2007). Oleh karena itu, penelitian laboratorium diperlukan untuk mengetahui hubungan fluk metana dan dinitrogen oksida dengan karakteristik tanah sawah tadah hujan.

\section{BAHAN DAN METODE}

Kegiatan penelitian dilaksanakan di Laboratorium Emisi dan Absorbsi Gas Rumah Kaca, Balai Penelitian Lingkungan Pertanian di Pati Jawa Tengah. Penelitian dilaksanakan menggunakan metode inkubasi dan contoh tanah Inceptisol diambil pada ekosistem sawah tadah hujan. Lokasi penelitian terletak pada koordinat $111^{\circ} 10^{\prime} \mathrm{BT}$ dan $6^{\circ} 45^{\prime} \mathrm{LS}, 17 \mathrm{~km}$ dari Pantai Utara Jawa Tengah (kecamatan Juana) dengan ketinggian $15 \mathrm{~m}$ di atas permukaan laut.

Contoh tanah diambil pada kedalaman $0-20$ cm (lapisan olah) pada posisi lereng bagian atas dan bagian bawah dalam suatu kemiringan tertentu atau toposekuen (3 lokasi berlereng), yang diilustrasikan pada Gambar 1. Setiap posisi diambil dari beberapa titik secara acak pada suatu hamparan persawahan \pm satu hektar dan dikompositkan. Contoh tanah komposit sebanyak $6 \mathrm{~kg}$ contoh diambil dari enam lokasi dari tiga lokasi berlereng di sekitar percobaan lapangan, yaitu toposekuen pertama dengan kemiringan 4,3\% (Tegalarum atas, Tegalarum bawah), toposekuen kedua dengan kemiringan 3,5\% (Mojoluhur atas, Mojoluhur bawah), dan toposekuen ketiga dengan kemiringan 4,8\% (Trikoyo atas, Sidomukti bawah). Contoh tanah dikeringanginkan dan diayak dengan ayakan berdiameter $2 \mathrm{~mm}$.

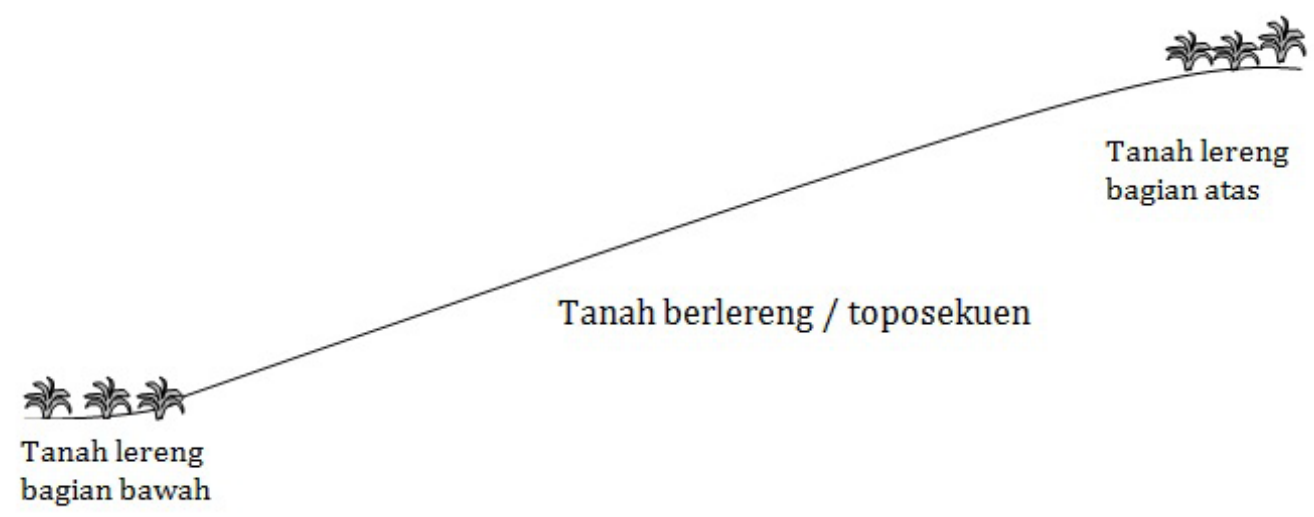

Gambar 1. Posisi pengambilan contoh tanah pada tanah sawah tadah hujan berlereng (toposekuen) 
Metode Pengukuran Produksi $\mathrm{CH}_{4}$ dan $\mathbf{N}_{2} \mathbf{O}$

Contoh tanah dianalisis menggunakan metode inkubasi untuk menetapkan potensi produksi gas metana dan dinitrogen oksida. Contoh tanah seberat 60 gram ditempatkan di gelas piala $300 \mathrm{ml}$, lalu ditambahkan $120 \mathrm{ml}$ air destilasi. Labu piala ditutup dengan penutup karet. Pada penutup karet dilengkapi dengan saluran untuk pemasukan gas $\mathrm{N}_{2}$. Masing-masing labu piala diinkubasi dalam inkubator atau dalam ruang gelap selama 1 bulan.

$$
\mathrm{C}_{\mathrm{i}}=\left(\mathrm{C}_{\mathrm{t}}-\mathrm{C}_{0}\right) \cdot \frac{V h s}{B} \cdot \frac{W m}{V m} \cdot \frac{273,2}{273,2+T}
$$

$\mathrm{C}_{\mathrm{i}}$ : potensi produksi $\mathrm{CH}_{4}$ atau $\mathrm{N}_{2} \mathrm{O}(\mu \mathrm{g} / \mathrm{g}$ tanah $)$

$\mathrm{C}_{\mathrm{t}}$ : kadar gas saat waktu t tertentu $(\mu \mathrm{l} / \mathrm{L})$

$\mathrm{C}_{0} \quad$ : kadar gas saat waktu awal $(\mu 1 / \mathrm{L})$

$\mathrm{V}_{\mathrm{hs}}$ : volume headspace $(\mathrm{ml})$

B : berat tanah $(\mathrm{g})$

$\mathrm{W}_{\mathrm{m}}$ : berat molekul $\mathrm{CH}_{4}$ atau $\mathrm{N}_{2} \mathrm{O}\left(10^{3} \mathrm{mg}\right)$

$\mathrm{V}_{\mathrm{m}}$ : volume molekul $\mathrm{CH}_{4}$ atau $\mathrm{N}_{2} \mathrm{O}$ kondisi standar $\left(22,41.10^{-3} \mathrm{ml}\right)$

$\mathrm{T}$ : suhu rata-rata dalam labu ukur saat pengukuran $\left({ }^{\circ} \mathrm{C}\right)$

Tabel 1. Metode analisis tanah yang digunakan dalam percobaan inkubasi di Laboratorium

\begin{tabular}{|l|l|}
\hline \multicolumn{1}{|c|}{ Analisis } & \multicolumn{1}{|c|}{ Metode } \\
\hline Fisika Tanah & Pipet \\
Tekstur & \\
& \\
Kimia Tanah & Elektroda (1:1) \\
pH-H2O dan pH-KCl & Konduktimetri \\
Daya hantar listrik (DHL) & Kjeldahl \\
$\mathrm{N}$ total & Walkley \& Black \\
C organik & - \\
Nisbah C/N & Bray 1 \\
P tersedia & HCl 25\% \\
P potensial & Penjenuhan NH4OAc pH 7 \\
KPK & Penjenuhan NH4OAc pH 7 \\
Kation-kation dapat ditukar (Ca, Mg, K, Na) & Spektrofotometer \\
SO4 tersedia & AAS \\
Fe tersedia & AAS \\
Mn tersedia & \\
Biologi Tanah & \\
Bakteri total & Plate dilution \\
Denitrifier & Most Probable Number \\
Respirasi tanah & Jar \\
\hline
\end{tabular}




\section{Pengumpulan Data}

Data yang dikumpulkan pada percobaan inkubasi di laboratorium meliputi laju produksi $\mathrm{CH}_{4}$ dan $\mathrm{N}_{2} \mathrm{O}$, tekstur tanah, $\mathrm{pH}$, daya hantar listrik, $\mathrm{N}$ total, $\mathrm{C}$ organik, Nisbah C/N, Nisbah $\mathrm{C} / \mathrm{P}$, Nisbah $\mathrm{C} / \mathrm{K}, \mathrm{P}$ tersedia, $\mathrm{K}$ tersedia, kapasitas tukar kation (KPK), kation-kation dapat ditukar (Ca, $\mathrm{Mg}, \mathrm{K}, \mathrm{Na}), \mathrm{SO}_{4}$ tersedia, Fe tersedia, Mn tersedia, respirasi tanah, bakteri total, populasi Denitrifier (Tabel 1).

\section{Analisis Data}

Data terkumpul dianalisis menggunakan analisis regresi linier sederhana atau regresi berganda dan uji korelasi untuk mengetahui hubungan antara produksi gas metana atau dinitrogen oksida dengan sifat-sifat tanah tertentu. Analisis sidik ragam digunakan untuk menguji pengaruh peubah bebas terhadap peubah tidak bebas. Keeratan hubungan antara produksi gas rumah kaca metana atau dinitrogen oksida dengan parameter fisikakimia tanah ditunjukkan oleh nilai r (koefisien korelasi).

\section{HASIL DAN PEMBAHASAN}

\section{Produksi Metana dan Dinitrogen Oksida Pada Tanah Sawah Tadah Hujan}

Potensi produksi metana dari tanah sawah tadah hujan pada bagian lereng atas adalah lebih tinggi daripada pada bagian lereng bagian bawah. Produksi metana dari tanah sawah Inceptisol yang diinkubasi selama 26 hari adalah 0,090 $\mathrm{mg} \mathrm{CH}_{4} \mathrm{~g}^{-1}$ tanah (tanah

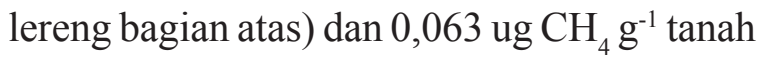
(Gambar 2). Laju produksi $\mathrm{CH}_{4}$ pada tanah lereng bagian atas sama dengan pada tanah lereng bagian bawah saat tanah diinkubasi selama 6 hari.


Gambar 2. Laju produksi gas metana dan dinitrogen oksida dari tanah sawah tadah hujan berbeda posisi dalam suatu toposekuen 
Potensi produksi dinitrogen oksida dari tanah sawah tadah hujan bagian atas adalah lebih tinggi daripada dari tanah sawah bagian bawah dalam suatu toposekuen (Gambar 2). Produksi $\mathrm{N}_{2} \mathrm{O}$ dari tanah lereng bagian atas sama dengan dari tanah lereng bagian bawah setelah tanah diinkubasi selama 26 hari. Produksi $\mathrm{N}_{2} \mathrm{O}$ dari tanah sawah Inceptisol setelah diinkubasi 26 hari adalah 10,1 ug $\mathrm{N}_{2} \mathrm{O} \mathrm{g}^{-1}$ tanah.

\section{Hubungan potensi produksi GRK dengan parameter tanah}

(1) Parameter Fisika-Kimia Tanah

Pada Tabel 2 terlihat bahwa produksi metana dari tanah sawah tadah hujan Inceptisol dipengaruhi secara nyata oleh kandungan $\mathrm{C}$ organik, nisbah $\mathrm{C} / \mathrm{P}$, nisbah $\mathrm{C} / \mathrm{S}$, sulfat tersedia, Mn tersedia, dan $\mathrm{Na}$ dapat ditukar. Produksi metana nyata berkorelasi positif

Tabel 2. Korelasi produksi metana dan dinitrogen oksida dalam tanah sawah dengan parameter fisika-kimia tanah

\begin{tabular}{|c|c|c|}
\hline \multirow{2}{*}{ Peubah fisikokimia tanah } & \multicolumn{2}{|c|}{ Nilai korelasi (r) } \\
\hline & Metana & Dinitrogen oksida \\
\hline$\%$ pasir & $0,633^{\text {th }}$ & $0,657^{\text {tn }}$ \\
\hline$\%$ debu & $-0,093^{\operatorname{tn}}$ & $0,254^{\text {tn }}$ \\
\hline$\%$ lempung & $-0,494^{\mathrm{tn}}$ & $-0,868^{*}$ \\
\hline $\mathrm{pH}$ & $0,073^{\text {th }}$ & $-0,739^{*}$ \\
\hline Daya hantar listrik & $-0,297^{\mathrm{tn}}$ & $-0,332^{\mathrm{tn}}$ \\
\hline C organik & $0,737 *$ & $0,079^{\text {tn }}$ \\
\hline $\mathrm{N}$ total & $-0,255^{\mathrm{tn}}$ & $0,286^{\mathrm{tn}}$ \\
\hline $\mathrm{N}-\mathrm{NO}_{3}$ & $0,621^{\mathrm{tn}}$ & $0,994 * * * *$ \\
\hline $\mathrm{N}-\mathrm{NH}_{4}$ & $0,424^{\text {tn }}$ & $0,271^{\mathrm{tn}}$ \\
\hline $\mathrm{S}$ total & $-0,177^{\mathrm{tn}}$ & $-0,626^{\mathrm{tn}}$ \\
\hline $\mathrm{SO}_{4}$ tersedia & $-0,969 * *$ & $-0,575^{\mathrm{tn}}$ \\
\hline P total & $-0,436^{\text {tn }}$ & $-0,162^{\mathrm{tn}}$ \\
\hline $\mathrm{P}$ terekstrak $\mathrm{HC} 125 \%$ & $-0,292^{\text {tn }}$ & $-0,168^{\mathrm{tn}}$ \\
\hline P terekstrak Bray 1 & $-0,141^{\mathrm{tn}}$ & $0,553^{\mathrm{tn}}$ \\
\hline Nisbah C/N & $0,225^{\mathrm{tn}}$ & $-0,493^{\text {tn }}$ \\
\hline Nisbah C/S & $0,838^{*}$ & $0,539^{\text {tn }}$ \\
\hline Nisbah C/P & 0,847 * & $0,389^{\text {tn }}$ \\
\hline Fe tersedia & $-0,006^{\mathrm{tn}}$ & $0,408^{\text {tn }}$ \\
\hline Mn tersedia & $-0,842 *$ & $-0,780 *$ \\
\hline Kapasitas tukar kation(KTK) & $-0,434^{\mathrm{tn}}$ & $-0,529^{\text {tn }}$ \\
\hline \multicolumn{3}{|l|}{ Kation dapat ditukar } \\
\hline $\mathrm{K}$-dd & $-0,378^{\mathrm{tn}}$ & $-0,342^{\text {tn }}$ \\
\hline Na-dd & $-0,819 *$ & $-0,151^{\text {th }}$ \\
\hline Ca-dd & $-0,168^{\operatorname{tn}}$ & $-0,646^{\mathrm{tn}}$ \\
\hline Mg-dd & $-0,578^{\mathrm{tn}}$ & $-0,507^{\mathrm{tn}}$ \\
\hline
\end{tabular}


dengan kandungan $\mathrm{C}$ organik dalam tanah, nisbah $\mathrm{C} / \mathrm{P}$, dan nisbah $\mathrm{C} / \mathrm{S}$, dan nyata berkorelasi negatif dengan ketersediaan sulfat, $\mathrm{Mn}, \mathrm{Na}$ _dd dalam tanah sawah.

Kandungan C organik dalam tanah terutama C siap termineralisasi adalah faktor utama yang mempengaruhi produksi dan emisi $\mathrm{CH}_{4}$ dari tanah tergenang. Karbon siap termineralisasi merupakan jumlah $\mathrm{C}-\mathrm{CO}_{2}$ dan $\mathrm{C}-\mathrm{CH}_{4}$ yang dihasilkan dari tanah segar yang diinkubasi selama 28 hari (Minami, 1995) yang menentukan besarnya potensi produksi metana dalam tanah. Menurut Wang et al. cit Neue \& Sass (1994), kandungan C organik total berkorelasi dengan produksi $\mathrm{CH}_{4}$ bilamana faktor pembatas lainnya dimitigasi.

Makin tinggi nisbah $\mathrm{C} / \mathrm{P}$ dan $\mathrm{C} / \mathrm{S}$ meningkatkan produksi metana. Nisbah $\mathrm{C} / \mathrm{N}, \mathrm{C} / \mathrm{P}, \mathrm{C} / \mathrm{K}$, $\mathrm{C} / \mathrm{S}$ di dalam tanah menunjukkan seberapa jauh bahan organik dimanfaatkan oleh mikroba tanah yang tergantung pada kandungan oksigen dan biomassa mikroba saat proses dekomposisi berlangsung. Dekomposisi bahan organik secara anaerobik akan dihasilkan hidrokarbon, alkohol, karbonil, asam lemak, asam fenolik, senyawa $\mathrm{S}$ volatil, dan senyawa yang mengandung fosfor. Tahap akhir transfer elektron dari degradasi anaerobik bahan organik menentukan laju dan pola pembentukan metana (Neue \& Roger, 1993), seperti peningkatan senyawa $\mathrm{S}$ volatil dan senyawa yang mengandung $\mathrm{P}$ akan mempengaruhi besarnya metana yang dihasilkan dalam tanah tergenang.

Hubungan potensi produksi metana dengan ketersediaan $\mathrm{SO}_{4}, \mathrm{Mn}, \mathrm{Na}$ dapat ditukar ditunjukkan dengan persamaan berikut :
Peningkatan ketersediaan $\mathrm{SO}_{4}, \mathrm{Mn}$, dan $\mathrm{Na}$ dapat ditukar dalam tanah sawah menghambat pembentukan $\mathrm{CH}_{4}$. Menurut Neue \& Sass (1994), oksidan tanah tergenang yang berupa $\mathrm{NO}_{3}^{-}, \mathrm{Mn}^{4+}, \mathrm{Fe}^{3+}, \mathrm{SO}_{4}^{2-}$ dapat menurunkan aktivitas metanogen. Tahapan termodinamika pada sistem oksidasi-reduksi dari tanah sawah mempengaruhi ketersediaan $\mathrm{SO}_{4}^{2-}, \mathrm{Mn}^{4+}, \mathrm{Na}^{+}$ dapat ditukar, dan pembentukan $\mathrm{CH}_{4}$. Metana terbentuk bila potensial redoks lebih rendah daripada $-150 \mathrm{mV}$ (Wang et al. cit Neue \& Sass, 1994). Peningkatan kandungan sulfat dan Mn akan dimanfaatkan secara lebih efisien oleh bakteri preduksi sulfat dan Mn. Pada lingkungan tanah anaerobik, bakteri metanogen, bakteri pereduksi sulfat, bakteri pereduksi $\mathrm{Mn}$, dan bakteri kemoacetogenik bersaing memanfaatkan $\mathrm{H}_{2}$ dan substrat asetat hasil fermentasi (Minamikawa et al., 2005). Bakteri pereduksi sulfat dapat bersaing melebihi bakteri metanogen dengan ketersediaan sulfat dalam tanah karena bakteri pereduksi sulfat mempunyai afinitas lebih tinggi terhadap $\mathrm{H}_{2}$, sehingga dapat menekan produksi metana (Abram \& Nedwell cit Neue \& Roger, 1993). Peningkatan Na_dd dalam tanah dapat menghambat aktivitas bakteri metanogen dalam menghasilkan metana. Hasil penelitian Patel \& Roth cit Neue (1993) menunjukkan bahwa peningkatan kadar $\mathrm{NaCl}$ mendekati 0,18 molar yang diberikan ke dalam tanah nyata menghambat metanogenesis.

Di antara parameter fisika-kimia tanah, hanya kandungan lempung, $\mathrm{pH}$, nitrat, dan $\mathrm{Mn}$ tersedia yang mempengaruhi secara nyata produksi $\mathrm{N}_{2} \mathrm{O}$ di tanah sawah tadah hujan yang berlereng (Tabel 3). Produksi $\mathrm{N}_{2} \mathrm{O}$ berkorelasi 
positif secara nyata dengan kandungan $\mathrm{NO}_{3}^{-}$, tetapi berkorelasi negatif secara nyata dengan kandungan lempung dan Mn tersedia dalam tanah. Hubungan produksi $\mathrm{N}_{2} \mathrm{O}$ dengan kandungan nitrat dan Mn tersedia ditunjukkan oleh persamaan berikut : rendah seperti kompos dan pemberian pupuk $\mathrm{N}$ ke dalam lapisan reduktif tanah atau dalam bentuk pupuk amonium sulfat (ZA) dalam memperbaiki produktivitas tanah sawah tadah hujan memberika emisi gas rumah kaca relatif rendah (Wihardjaka, 2005).

$$
\mathrm{N}_{2} \mathrm{O}=-3,25+0,365 \mathrm{NO}_{3}+0,00148 \text { Mntersedia }\left(\mathrm{R}^{2}=0,991 ; \mathrm{p}<0,01\right)
$$

Peningkatan Mn tersedia dalam tanah menghambat produksi $\mathrm{N}_{2} \mathrm{O}$ diduga bahan kimia seperti Mn bersifat toksik bagi bakteri nitrifikasi dan denitrifikasi (Granli \& Bockman, 1994). Tingginya kandungan lempung justeru menurunkan produksi $\mathrm{N}_{2} \mathrm{O}$, diduga tingginya lempung berpengaruh terhadap distribusi ukuran pori yang menghambat ebulisi dan difusi $\mathrm{N}_{2} \mathrm{O}$ ke atmosfer karena sebagian $\mathrm{N}_{2} \mathrm{O}$ yang terperangkap direduksi menjadi $\mathrm{N}_{2}$ sebelum dapat lepas ke atmosfer (Neue \& Sass, 1994; Verchot et al., 2008).

Produksi $\mathrm{N}_{2} \mathrm{O}$ berkorelasi positif dengan tingkat $\mathrm{NO}_{3}^{-}$dalam tanah. Akumulasi $\mathrm{NO}_{3}^{-}$dalam lapisan reduktif tanah sawah menguntungkan bakteri denitrifikasi karena ketersediaan substrat dalam proses reduksi nitrat menjadi $\mathrm{N}_{2} \mathrm{O}$ dan $\mathrm{N}_{2}$. Peningkatan ketersediaan $\mathrm{N}$ terutama nitrat umumnya memacu peningkatan produksi dan emisi $\mathrm{N}_{2} \mathrm{O}$ karena stimulasinya terhadap proses mikrobiologis denitrifikasi yang menghasilkan fluk $\mathrm{N}_{2} \mathrm{O}$ dan $\mathrm{N}_{2}$ (Verchot et al., 2008).

Hubungan positif antara produksi metana dan dinitrogen oksida dan beberapa parameter tanah berimplikasi terhadap pengelolaan tanah sawah tadah hujan dalam budidaya tanaman pangan terutama padi sawah. Pemberian bahan organik dengan nisbah $\mathrm{C} / \mathrm{N}$
(2) Parameter Biologi Tanah

Tabel 4 terlihat bahwa potensi produksi metana dipengaruhi secara nyata oleh populasi bakteri total dalam tanah dan respirasi tanah $(\mathrm{p}<0,05)$. Peningkatan populasi bakteri dalam tanah sawah berkorelasi nyata dengan respirasi tanah $(r=0,95)$. Respirasi tanah merupakan suatu indikator yang baik untuk alokasi karbon, dan bakteri metanogen membutuhkan substrat seperti asetat, $\mathrm{CO}_{2}$ pada kondisi anaerobik untuk menghasilkan metana (Verchot et al., 2008).

Produksi $\mathrm{N}_{2} \mathrm{O}$ dalam tanah berkorelasi positif secara nyata dengan populasi Nitrosomonas ( $p$ $<0,01$ ) dan populasi bakteri denitrifikasi ( $\mathrm{p}<$ $0,05)$ seperti terlihat pada Tabel 4. Beberapa faktor mempengaruhi produksi dan emisi $\mathrm{N}_{2} \mathrm{O}$ dalam tanah, antara lain : kadar oksigen dalam tanah, tekstur tanah, jumlah $\mathrm{NH}_{4}^{+}$tersedia bagi bakteri nitrifikasi, dan jumlah $\mathrm{NO}_{3}^{-}$tersedia bagi bakteri denitrifikasi (Snyder et al., 2009). Gas $\mathrm{N}_{2} \mathrm{O}$ adalah hasil antara dari proses transformasi $\mathrm{NO}_{2}^{-}$pada kondisi $\mathrm{O}_{2}$ terbatas ketika bakteri nitrifikasi menggunakan $\mathrm{NO}_{2}^{-}$ sebagai akseptor elektron terminal. Bakteri Nitrosomonas dan Nitrobacter merupakan bakteri kemoautotrof yang memperoleh energi dengan mengoksidasi $\mathrm{NH}_{4}^{+}$menjadi $\mathrm{NO}_{2}^{-}$(66 Kkal) dan oksidasi $\mathrm{NO}_{2}^{-}$menjadi 
Tabel 4. Korelasi produksi metana dan dinitrogen oksida dalam tanah sawah dengan parameter biologi tanah

\begin{tabular}{lcc}
\hline \multirow{2}{*}{ Peubah biologi tanah } & \multicolumn{2}{c}{ Nilai korelasi (r) } \\
\cline { 2 - 3 } & Metana & Dinitrogen oksida \\
\hline Bakteri total & $0,840^{*}$ & $0,353^{\text {tn }}$ \\
Mikroba pelarut fosfat & $0,439^{\text {tn }}$ & $0,118^{\text {tn }}$ \\
Bakteri Nitrosomonas & $0,800^{*}$ & $0,947^{* *}$ \\
Bakteri denitrifikasi & $0,665^{\text {th }}$ & $0,890^{*}$ \\
Respirasi tanah & $0,849^{*}$ & $0,167^{\text {tn }}$ \\
\hline
\end{tabular}

Keterangan : $*=$ nyata pada taraf $5 \%, \quad * *=$ nyata pada taraf $1 \%, \quad$ tn $=$ tidak nyata

$\mathrm{NO}_{3}^{-}$(18 Kkal). Di dalam tanah selain kedua bakteri tersebut dijumpai pula bakteri lain yang berperan dalam nitrifikasi yaitu bakteri autotrof obligat murni seperti Nitrosococcus, Nitrosospira, Nitrosocystis, Nitrosogloea, dan Nitrocystis. Pertumbuhan bakteri nitrifikasi dalam tanah tergantung pada ketersediaan $\mathrm{NH}_{4}^{+}$dan $\mathrm{NO}_{2}^{-}$, aerasi, kelembaban, suhu, $\mathrm{pH}$ dan bahan organik (Rao, 1994).

Bakteri denitrifikasi nyata berpengaruh terhadap pelepasan $\mathrm{N}_{2} \mathrm{O}$ ke atmosfer. Peningkatan populasi bakteri denitrifikasi memberi peluang tinggi terhadap reduksi nitrat dan nitrit menjadi $\mathrm{N}_{2} \mathrm{O}$ dan $\mathrm{N}_{2}$. Bakteri denitrifikasi menggunakan $\mathrm{O}_{2}$ di atmosfer sebagai akseptor hidrogen pada kondisi tanah aerob tetapi juga mempunyai kemampuan menggunakan $\mathrm{NO}_{3}^{-}$dan $\mathrm{NO}_{2}^{-}$sebagai pengganti $\mathrm{O}_{2}$ pada kondisi tanah anaerob. Beberapa genus bakteri denitrifikasi banyak dijumpai dalam tanah adalah Pseudomonas, Achromobacter, dan Bacillus (Rao, 1994).

\section{KESIMPULAN}

- Peningkatan potensi produksi metana dari tanah sawah tadah hujan Inceptisol dipengaruhi secara nyata oleh tingginya kandungan $\mathrm{C}$ organik dalam tanah dan rendahnya ketersediaan sulfat dan mangan dalam tanah.
- Peningkatan potensi produksi dinitrogen oksida dari tanah sawah tadah hujan Inceptisol dipengaruhi secara nyata oleh tingginya kandungan nitrat dalam tanah dan rendahnya ketersediaan mangan dalam tanah dan kandungan lempung.

- Pelepasan metana dan dinitrogen oksida dalam tanah ke atmosfer ditentukan oleh karakteristik fisik, kimia dan hayati tanah sawah tadah hujan, seperti kandungan bahan organik, ketersediaan hara esensial tanaman, dan aktivitas mikroba dalam tanah.

\section{DAFTAR PUSTAKA}

(1) Cortons, T.M., J.B. Bajita, F.S. Grospe, R.R. Pamplona, C.A. Aziz Jr., R. Wassmann, R. S. Lantin, \& L.V. Buendia. 2000. Methane Emission from Irrigated and Intensively Managed Rice Fields in Central Luzon, Philippines. Nutrient Cycle in Agroecosystems. 58 : 37-53.

(2) Granli, T., \& O.C. Bockman. 1994. Nitrous Oxide from Agriculture. Norwegian J. Agric. Sci. Suppl. No. 12. p. 1-159. 
(3) Jain, M.C., S. Kumar, R. Wassmann, S. Mitra, S.D. Singh, J. P. Singh, R. Singh, A.K. Yadav, \& S. Gupta. 2000. Methane Emissions from Irrigated Rice Fields in Northen India, NewDelhi. Nutrient Cycle in Agroecosystems 58 : 75-83.

(4) Johnson, J.M.F., A.J. Franzluebbers, S.L. Weyers, \& D.C. Reicosky. 2007. Agricultural opportunity to mitigate green house gas emissions. Environmental Pollution 150 : 107124.

(5) Ko, J.Y., \& H.W. Kang. 2000. The Effect of Cultural Practices on Methane Emission from Rice Fields. Nutrient Cycle in Agroecosystem 58 : 311-314.

(6) Minami, K. 1995. The Effect of Nitrogen Fertilizer Use and Other Practices on Methane Emission from Flooded Rice. Fertilizer Research 40 : 71-84.

(7) Neue, H.U. 1993. Methane Emission from Rice Field : Wetland Rice Fields May Make A Major Contribution to Global Warming. BioScience 43(7) : 466-473.

(8) Neue, H.U., \& P.A. Roger. 1993. Rice Agriculture: Factors Controlling Emission. In: Khalil, M.A.K., and M. Shearer (Eds.). Global Atmospheric Methane. NATO ASI/ARW Series.

(9) Neue, H.U., \& R.L. Sass. 1994. Trace Gas Emission from Rice Fields. Environ. Sci. Res. 48 : 119 - 147.
(10) Rao, N.S.S. 1994. Mikroorganisme Tanah dan Pertumbuhan Tanaman. Terjemahan Herawati Susilo dan Subiyanto. UI-Press, Indonesia. 353p.

(11) Snyder, C.S., T.W. Bruulsema, T.L. Jensen, \& P.E. Fixen. 2009. Review of Greenhouse Gas Emissions from Crop Production Systems and Fertilizer Management Effects. Agric. Ecosyst. Environ. 133 : 247-266.

(12) Verchot, L.V., S.B. Junior, V.C. de Oliveira, J.K. Mutegi, J.H. Cattanio, \& E.A. Davidson. 2008. Fluxes of $\mathrm{CH}_{4}, \mathrm{CO}_{2}, \mathrm{NO}$, and $\mathrm{N}_{2} \mathrm{O}$ in $\mathrm{An}$ Improved Fallow Agroforestry System in Eastern Amazonia. Agric. Ecosyst. Environ. 126 : 113-121.

(13) Wassmann, R., \& A. Dobermann. 2006. Greenhouse gas emission for rice fields : What do we know and where should we head for? The 2 nd Joint International Conference on Sustainable Energy and Environment (SEE 2006). Bangkok, Thailand, 2123 May 2006. 5p.

(14) Wihardjaka, A. 2005. Fluks metana pada beberapa komponen teknologi sawah tadah hujan di Kabupaten Pati. Prosiding Seminar Nasional Inovasi Teknologi Pengelolaan Sumberdaya Lahan Rawa dan Pengendalian Pencemaran Lingkungan, Banjarbaru Kalimantan Selatan, 5-7 Oktober 2004. p. 425-441. 